\title{
단기간의 교정운동이 골반전방경사 환자의 통증, 엉덩관절 가동범위 및 몸통근력에 미치는 영향. 증례보고
}

박상호 · 김아람 · 이호성

단국대학교

\begin{abstract}
Sang-Ho Park · Ah-Ram Kim · Ho-Seong Lee. Effects of Short-term Corrective Exercise on Pain, Hip Joint Range of Motion and Trunk Muscle Strength of a Patient with Anterior Pelvic Tilt: A Case Study. KINESIOLOGY, 2016, 18(3): 85-93. [PURPOSE] The purpose of this case report was to determine the effects of short-term corrective exercise on pain, hip Joint range of motion and trunk muscle strength of a patient with anterior pelvic tilt (APT). [METHODS] The single-subject was a 21-year-old female with APT and low back pain (LBP). Corrective exercise program was performed for $40 \mathrm{~min} /$ day twice a week for 4-week. LBP (VAS), lumbar disability (ODI), range of motion (hip flexion, extension, abduction, adduction, internal rotation, and external rotation) and trunk flexor and extensor strength were measured before and after 4 weeks of corrective exercise. [RESULTS] VAS and ODI decreased after corrective exercise. Hip joint range of motion increased at flexion, extension, abduction, adduction, internal rotation, and external rotation after corrective exercise. Trunk flexor and extensor strength improved after corrective exercise. [CONCLUSIONS] We demonstrated that short-term corrective exercise decreases pain and disability, increases range of motion, trunk flexor, and extensor strength of a patient with anterior pelvic tilt.
\end{abstract}

Key words : anterior pelvic tilt, short-term corrective exercise, low back pain, hip joint range of motion 주요어 : 골반전방경사, 단기간 교정운동, 요통, 엉덩관절 가동범위

\section{서론}

일반적으로 골반의 자세는 척추 및 주변 관절의 문제 를 측정하는데 사용할 수 있으며(Youdas et al., 1996), 골반 위치의 변형은 신경 근골격계(neuromusculoskeletal) 장애에 대한 다양한 자세적 보상을 통해 발생하고(Juhl et al., 2004), 장시간 자세적 보상을 통한 골반 위치의 변화는 다양한 근골격계 질환을 야기한다(Sahrmann, 2002). 골반 위치의 변형 중에서도 골반 앞 기울임 (anterior pelvic tilt; $\mathrm{APT}$ )은 장시간 잘못된 자세에 의해 골반이 엉덩관절의 가로축(transverse axis) 앞으로 회전 하여 발생하는 것으로 알려져 있으며, 허리뼈의 과도한 폄(extensor)과 엉덩관절의 굽힘(flexor)을 동반하여 결과 적으로 골반 및 골반 주위 근육과 인대에 가해지는 부 하의 증가 및 비정상적 허리뼈 전만의 발생으로 인해 요통 및 앞 십자인대의 약화를 포함한다고 보고하였다 (Waryasz, 2010). 또한 APT는 복부 근육군 및 엉덩관절
폄근의 약화, 척추 주변근의 경직 및 유연성 감소가 주 된 원인으로 야기되며(Levine et al., 1997), 전만 자세 (lordotic posture)를 발생시킨다(Endo et al., 2012). 이 중에서도 복부 근육군의 약화는 과도한 $\mathrm{APT}$ 및 허리척 추앞굽음을 증가시키는 가장 주된 원인으로(Kisner \& Colby, 2002; Levine et al., 1997), 복부 근육군의 약화가 발생하면 정상 정렬의 골반에 늘어짐(elongation)의 발생 과 더불어 전방으로 과도한 치우침(deviation)을 야기하 며, 이로 인해 허리척추앞굽음각이 증가하게 된다고 하 였다(Levine et al., 1997).

또한, 몸통이 안정화 상태일 때 복부 근육군의 수 축은 골반을 후방 자세로 치우치게 된다고 하였으며 (Kendall \& McCreary, 1983), 복부 근육군의 장시간 의 늘어짐은 골반의 치우침을 발생시키며, 근육의 신 장-약화를 발생시킨다고 하였다(Kendall et al., 1977). 이러한 관점에서 복부 근육군의 강화운동은 과도한 $\mathrm{APT}$ 및 허리뼈 전만의 치료적 접근 방법으로 현장에

* 교신저자: hoseh28@dankook.ac.kr 
서 흔히 사용된다고 하였으며(Levine et al., 1997), 선 행연구에 의하면, $\mathrm{APT}$ 환자에게 복부근력 강화운동이 $\mathrm{APT}$ 와 골반 불균형 장애를 감소시켰다고 보고하였다 (Schache et al., 2000). 또한 Choi et al.(2015)은 복부 근육군의 약화뿐만 아니라 장시간 앉은 자세에서 기 인하는 큰볼기근(gluteus maximus)의 약화와 신장도 $\mathrm{APT}$ 를 발생시키는 주요 원인 중 하나라고 하면서, $\mathrm{APT}$ 환자 21명을 대상으로 일회성 교각운동을 적용 한 결과, 큰볼기근의 활성을 증가시키고, $\mathrm{APT}$ 의 각도 를 감소시킨다고 보고하였다. Oh et al.(2007)은 APT 의 예방 및 치료를 목적으로 엎드린 자세에서 엉덩관 절 폄 운동과 복부 드로우 인 기법(abdominal draw-in maneuver)을 동반한 엎드린 자세에서 엉덩 관절 폄 운동을 비교한 결과, 엎드린 자세에서 엉덩관 절 폄 운동과 비교해서 복부 드로우 인 기법을 동반 한 엎드린 자세에서 엉덩관절 폄 운동이 큰볼기근의 근활성도가 증가하였고, 척추기립근의 근활성도의 감 소 및 전방골반경사의 감소가 나타났다고 하였다.

한편 선행연구에 의하면, 요골반(lumbo-pelvic)의 움직임은 요부 근육과 엉덩관절 주변 근육들의 균형 적인 활성이 나타나며, 요골반의 안정과 신체의 균형 적 움직임을 위해서는 엉덩관절과 몸통의 균형적 근 육활성이 중요하다고 보고하였다(Tateuchi et al., 2012). APT 및 APT에 의해 발생한 허리척추앞굽음은 엉덩관절과 몸통의 균형적 근육활성의 장애를 발생시 키며, 요골반에서 발생하는 움직임의 양상의 변화를 발생시킨다고 보고하면서, APT의 치료를 위해서는 엉 덩관절과 몸통 근육군의 균형적 강화가 필요하다고 하였다(Tateuchi et al., 2013). 또한 Waryasz (2010)는 $\mathrm{APT}$ 에 따른 척추 및 주변 관절에 특이적 위험성을 감소시키고 재활 기간의 최소화를 위해서는 복부 근 육의 강화뿐만 아니라 넙다리 뒷근육 및 엉덩관절 벌 림근(abductor muscle)의 강화와 척추 주변근, 엉덩관 절 모음근(adductor muscle) 및 굽힘근(flexor muscle) 의 신장에 초점에 맞춘 교정운동 프로그램을 구성하 여 적용해야 한다고 하였다. 하지만, APT 환자를 대 상으로 복부근육의 운동뿐만 아니라 몸통 및 엉덩관 절의 균형적 향상을 위한 교정 운동프로그램을 적용 하여 통증, 엉덩관절 가동범위 및 몸통 근력에 미치는 영향을 검토한 사례는 매우 제한된 숫자에 불과하다.
따라서 이 사례연구에서는 $\mathrm{APT}$ 환자를 대상으로 복부 근력 강화 및 엉덩관절 신장에 초점을 맞춘 4 주 간의 교정운동이 통증, 엉덩관절 가동범위 및 몸통 근 력에 미치는 영향을 확인하고, $\mathrm{APT}$ 환자의 치료를 위 한 교정운동의 기초자료를 제공하는데 목적이 있다.

\section{연구방법}

\section{연구대상}

이 사례연구의 대상은 방사선 검사상 허리척추앞굽음 각(L1-S1)이 $6219^{\circ}$ 이며, 엉치 수평각(sacral horizontal angle)이 $45.17^{\circ}$ 인 골반 앞기울임(APT)을 가진 생산직에 재직 중인 21세 여성으로 2015년 11월에 C지역 소재 M 센터에 내원하였으며, 요통 및 하지의 불편함을 호소하 였고 엉덩관절 움직임 시 끝범위에서 뺏뻣함(stiffness) 관찰할 수 있었다. 대상자의 신체적 특성은 <Table 1>에 제시하였다. 대상자에게는 사례연구의 취지 내용을 충분 설명한 후 자발적으로 참가 동의를 얻었다.

Table 1. Physical characteristic of subjects

\begin{tabular}{cccc}
\hline height $(\mathrm{cm})$ & weight $(\mathrm{kg})$ & body fat $(\%)$ & muscle mass $(\mathrm{kg})$ \\
\hline \hline 159.00 & 46.30 & 10.80 & 19.90 \\
\hline
\end{tabular}

\section{측정항목 및 방법}

\section{1) 신체조성}

신체조성은 신장계|Inbody BSM 330, Biospace, Korea)를 이용하여 신장을 측정하였으며, 체성분 분석 기(Inbody 770, Biospace, Korea)를 이용하여 체중, 체 지방률 및 근육량을 운동 전(pre) 및 운동 4 주 후 (post)에 각각 측정하였다. 대상자는 몸에 부착된 금 속성 물질을 제거한 후 측정 장치에 올라서서 발 전 극을 밟은 후 손잡이를 들고 직립 자세로 팔과 다리 를 약간 벌린 자세에서 양손에 전극을 누른 자세로 측정하였다(Lee \& Kim, 2016). 


\section{2) 통증 관련 지표}

통증 관련 지표는 오스웨스트리 장애지수(oswestry disability index; ODI) 및 시각상사척도(visual analogue scale; VAS)를 이용하여 측정하였다. ODI는 통증강도, 개인적 관리, 들기, 걷기, 앉아 있기, 서있기, 잠자기, 성생활, 사회생활 및 여행을 포함한 10 개의 문 항으로 되어 있다. 참여자의 수행 정도에 따라 0점에서 통증으로 인한 최악의 상태를 5점까지 부여한다 (Mousavi et al., 2006). 이러한 장애지수는 선택한 항 목의 점수를 총 점수로 나누고 100 을 곱하여 계산한다. 계산된 장애지수에서 $0-20 \%$ 는 경미한 장애(minimal disability), 21-40\%는 중등도 장애(moderate disability), 41-60\%는 중증장애(severe disability), $61-80 \%$ 는 지체부 자유자(crippled) 및 81-100\%는 누워만(bed-bound)있는 완전한 장애 또는 과장된(exaggerating)환자로 나눈다 (Little \& MacDonald, 1994). VAS는 통증의 정도를 알 아보기 위한 척도로 이용되며 척도는 0 에서 10 까지 눈 금이 표시되어 있는 $10 \mathrm{~cm}$ 가로의 선에 연구 대상자가 직접 표시하게 하였다. 0 의 위치를 통증이 전혀 없는 상태, 10 의 위치를 가장 심한 상태를 나타내고 거리를 측정하여 점수화하는 방법이다(Brodie et al. 1990).

\section{3) 엉덩관절 가동범위}

엉덩관절 가동범위는 전자 각도계(Baseline®, Fabrication Enterprises Inc,White Plains, NY, USA)를 이용하여 굽힘, 폄, 벌림, 모음, 안쪽 돌림 및 바깥 돌 림의 각도를 측정하였다. 엉덩관절 굽힘 가동범위는 바로 누운 자세에서 무릎관절을 폄 상태로 골반을 고 정시키고 넙다리 빼머리를 중심축으로 몸통과 평행한 선과 넙다리골 대결절과 넙다리골 외과까지 연결된 선이 이루는 각을 측정하였다. 엉덩관절 폄 가동범위 는 엎드린 자세에서 골반을 고정시키고 무릎관절을 굽힌 상태에서 넙다리 뼈머리를 중심축으로 몸통과 평행한 선과 넙다리골 결절과 넙다리골 외과로 연결 된 선이 이루는 각을 측정하였다. 엉덩관절 벌림 가동 범위는 바로 누운 자세에서 양쪽 다리를 중립위로 하 고 $10^{\circ}$ 벌림 상태에서 골반을 안정화한 후 고정시킨 다음 대상자의 발목을 잡고 부드럽게 벌릴 수 있는 만큼 움직인 후에 중심축을 동측 전상장골극에 놓고 반대 측 전상장골극으로 각도계의 한쪽을 향하게 한
후 무릎뼈 중심을 따라 엉덩관절 벌림 각을 측정하였 다(Kim et al., 2014). 엉덩관절 모음 가동범위는 바로 누운 자세에서 양쪽 다리를 중립위로 한 후 골반을 고정시키고 반대측 하지를 벌림 후에 검사 측 하지를 신체의 정중선을 가로질러 반대측으로 움직이며, 벌림 각의 측정 방법과 동일하게 실시하였다. 엉덩관절 안 쪽 돌림 및 바같 돌림 가동범위는 앉은 자세에서 측 정하였다(Kim et al., 2014). 보조 검사자는 대상자의 골반이 후방 경사되거나 몸통이 후방으로 이동하지 않도록 고정하였으며, 앉은 자세에서 엉덩관절과 무릎 관절이 $90^{\circ}$ 가 되도록 하고 넙다리뼈와 무릎뼈를 중립 위로 한 후 정강뼈머리를 중심축으로 수직선에서 정 강빼선을 따라 발목의 중심부까지 범위를 측정하였다. 모든 관절가동범위 검사는 각 3 회씩 반복 측정하여 그 평균값을 사용하였다. 엉덩관절 및 허리뼈 가동범 위는 pre 및 post에 동일한 방법으로 측정하였다.

\section{4) 몸통 폄 및 굽힘 근력}

몸통 폄 및 굽힘 근력은 lumbar extension exercise system (LEX system; DaeYang mechanics, Korea)을 이 용하여 측정하였다(Lee, 2015). 몸통 근력은 LEX system 을 이용하여 Graves et al.(1994)의 연구에서 정의된 허 리뼈-골반 리듬에 따라 $110^{\circ}-182^{\circ}$ 에서 $12^{\circ}$ 간격으로 총 7 개의 각도 $\left(110^{\circ}, 112^{\circ}, 134^{\circ}, 146^{\circ}, 158^{\circ}, 170^{\circ}, 182^{\circ}\right)$ 로 근력 측정을 실시하였으며, 몸통 근력 측정 전에 대상자에 게 측정 방법과 주의사항에 대해 충분히 설명하였다. 몸통 근력을 측정하기 위해 LEX system에 앉아 종아 리와 넙다리의 하지를 고정대로 고정하여 골반의 안정 화를 유지 하였으며, 상해 예방과 원활한 측정을 위하 여 등장성(isotonic)운동을 5 회 실시하였다. 측정자의 구령에 맞추어 대상자가 몸통을 폄 및 굽힘 시 등쪽 의 패드를 서서히 밀거나 당겨 2-3초간 최대근력이 발 휘되면 1-2초간 최대근력을 유지하여 측정하였다. 몸 통 근력은 pre 및 post에 동일한 방법으로 측정하였다.

\section{5) 허리척추앞굽음각 및 엉치 수평각}

허리척추앞굽음각 및 엉치 수평각은 피험자가 직립 해 있는 자세에서의 정적 단순 방사선 검사로 시상면 의 허리척추앞굽음각 및 엉치 수평각을 각각 측정하 였다. 허리척추앞굽음각은 제 1 허리뼈 상단과 제 1 엉치 
Table 2. Corrective exercise programl

\begin{tabular}{|c|c|c|c|}
\hline Order (time) & peroid & type & intensity \\
\hline $\begin{array}{l}\text { Warm-up } \\
(5 \mathrm{~min})\end{array}$ & & $\begin{array}{l}\text { Unilateral standing hamstring stretch, } \\
\text { Bilateral stretching while sitting in a stool, } \\
\text { Unilateral stretching while lying supine, } \\
\text { Bilateral standing hamstring stretch }\end{array}$ & $\begin{array}{c}\text { 3 rep } \\
\text { hold for } 20 \mathrm{sec} \\
\text { Between exercise: } 30 \mathrm{sec}\end{array}$ \\
\hline $\begin{array}{l}\text { Exercises } \\
\text { (30 min) }\end{array}$ & 1 4 week & $\begin{array}{c}\text { Abdominal crunch, } \\
\text { Prone hip extension, } \\
\text { Plank exercise with posterior tilt, } \\
\text { Bridging with isometric hip abduction, } \\
\text { Posterior pelvic tilting exercise with swiss-ball }\end{array}$ & $\begin{array}{c}10 \text { rep x } 2 \text { set } \\
\text { Rest } \\
\text { Between set: } 30 \mathrm{sec} \\
\text { Between exercise: } 60 \mathrm{sec}\end{array}$ \\
\hline $\begin{array}{l}\text { Cool-down } \\
\text { (5 min) }\end{array}$ & & $\begin{array}{l}\text { Unilateral standing hamstring stretch, } \\
\text { Bilateral stretching while sitting in a stool, } \\
\text { Unilateral stretching while lying supine, } \\
\text { Bilateral standing hamstring stretch, }\end{array}$ & $\begin{array}{c}3 \text { rep } \\
\text { hold for } 20 \mathrm{sec} \\
\text { Between exercise: } 30 \mathrm{sec}\end{array}$ \\
\hline
\end{tabular}

뼈 상단에 평행한 선을 그었을 때 교차되는 각을 측 정하였으며, 정상범위는 $50.40 \pm 10.93^{\circ}$ 로 보고하였다 (Sarikaya et al., 2007). 또한 엉치 수평각은 제 1 엉치 빼 상단과 수평면을 연결했을 때 형성되는 각으로 정 상범위는 $31.77 \pm 6.02^{\circ}$ 로 보고하였다(Kim et al., 2006).

\section{교정운동 프로그램}

이 사례연구에서 사용한 교정운동은 <Table 2>와 같으며, Waryasz (2010) 및 López-Miñarro et al.(2012) 의 연구에서 사용한 교정운동 프로그램과 넙다리 뒤 근육 스트레칭 운동을 수정 및 보완하여 수행하였다. 먼저 준비운동으로 5 분간의 넙다리 뒤근육 스트레칭 을 실시하였고, 본 운동은 복부 근육군의 강화 및 $\mathrm{APT}$ 개선을 위한 프로그램으로 구성하여 1 명의 치료 사에 의해 진행하였다. 교정운동은 복부 크런치 (abdominal crunch)운동, 엎드린 자세에서 엉덩관절 폄운동, $\mathrm{APT}$ 를 동반한 플랭크(plank) 운동, 엉덩관절 모음근의 등척성 수축을 동반한 교각운동 및 스위스 볼을 이용한 골반 뒤기울이기 운동을 10회 2세트 실 시하였다. 세트 간 휴식시간은 30초, 운동 간 휴식시 간은 60 초간으로 설정하였다. 본 운동 후 정리운동으 로 5 분간의 넙다리 뒤근육 스트레칭을 실시하였다. 교 정운동은 1 일 40 분, 주 2 회 및 4 주간에 걸쳐서 실시하 였다.

\section{결과}

1) 통증 관련 지표의 변화
VAS 및 ODI의 변화는 <Table 3>에 제시한 바와 같다. VAS는 pre의 $72.00 \mathrm{~mm}$ 와 비교해서 post에 $13.00 \mathrm{~mm}$ 로 감소하였다. ODI는 pre의 $36 \%$ 와 비교해 서 post에 $10 \%$ 로 감소하였다.

Table 3. Changes in VAS and ODI before (pre) and after 4-week (post) corrective exercise

\begin{tabular}{cccc}
\hline & pre & post & change (\%) \\
\hline \hline ODI (\%) & 36.00 & 10.00 & -72.22 \\
VAS (mm) & 72.00 & 13.00 & -81.94 \\
\hline VAS = Visual analogue scale; ODI = Oswestry disability \\
index; change = the ratio of pre to post
\end{tabular}

\section{2) 엉덩관절 가동범위의 변화}

엉덩관절 가동범위의 변화는 <Table 4 >에 제시한 바와 같다. 굽힘의 가동범위는 오른쪽 하지에서 pre에 $109.80^{\circ}$ 와 비교해서 post에 $119.80^{\circ}$ 로 증가하였으며, 왼 쪽 하지에서 pre에 $101.60^{\circ}$ 와 비교해서 post에 $121.60^{\circ}$ 로 증가하였다. 폄의 가동범위는 오른쪽 하지에서 pre 에 $23.50^{\circ}$ 와 비교해서 post에 $33.50^{\circ}$ 로 증가하였으며, 왼쪽 하지에서 pre에 $17.30^{\circ}$ 와 비교해서 post에 $24.70^{\circ}$ 로 증가하였다. 모음의 가동범위는 오른쪽 하지에서 pre에 $30.30^{\circ}$ 와 비교해서 post에 $3230^{\circ}$ 로 증가하였으 며, 왼쪽 하지에서 pre에 $28.10^{\circ}$ 와 비교해서 post에 $39.00^{\circ}$ 로 증가하였다. 벌림의 가동범위는 오른쪽 하지 에서 pre에 $30.50^{\circ}$ 와 비교해서 post에 $35.00^{\circ}$ 로 증가하 였으며, 왼쪽 하지에서 pre에 $3210^{\circ}$ 와 비교해서 post 에 $37.40^{\circ}$ 로 증가하였다. 안쪽 돌림의 가동범위는 오른 쪽 하지에서 pre에 $17.90^{\circ}$ 와 비교해서 post에 $36.50^{\circ}$ 로 증가하였으며, 왼쪽 하지에서 pre에 $22.80^{\circ}$ 와 비교해서 
post에 $37.70^{\circ}$ 로 증가하였다. 바깥 돌림의 가동범위는 오른쪽 하지에서 pre에 $21.10^{\circ}$ 와 비교해서 post에 $30.50^{\circ}$ 로 증가하였으며, 왼쪽 하지에서 pre에 $20.30^{\circ}$ 와 비교해서 post에 $25.70^{\circ}$ 로 증가하였다.

Table 4. Changes in hip joint ROM before (pre) and after 4-week (post) corrective exercise

\begin{tabular}{ccccccc}
\hline & \multicolumn{2}{c}{ pre } & \multicolumn{2}{c}{ post } & \multicolumn{2}{c}{ change (\%) } \\
\cline { 2 - 7 } & Rt & Lt & Rt & Lt & Rt & Lt \\
\hline \hline Flx $\left({ }^{\circ}\right)$ & 109.80 & 101.60 & 119.80 & 121.60 & 9.11 & 19.69 \\
Ext $\left({ }^{\circ}\right)$ & 23.50 & 17.30 & 33.50 & 24.70 & 42.55 & 42.77 \\
Add ( $\left(^{\circ}\right)$ & 30.30 & 28.10 & 32.30 & 39.00 & 6.60 & 38.79 \\
Abd ( $\left(^{\circ}\right)$ & 30.50 & 32.10 & 35.00 & 37.40 & 14.75 & 16.51 \\
IR ( $\left(^{\circ}\right)$ & 17.90 & 22.80 & 36.50 & 37.70 & 103.91 & 65.35 \\
ER $\left({ }^{\circ}\right)$ & 21.10 & 20.30 & 30.50 & 25.70 & 44.55 & 26.60 \\
\hline
\end{tabular}

Rt - right; Lt - left; Flx - flexion; Ext - Extension; Add adduction; Abd - abduction; IR - internal rotation; ER - external rotation change $=$ the ratio of pre to post

\section{3) 몸통 폄 및 굽힘 근력의 변화}

몸통 폄 및 굽힘 근력의 변화는 <Fig. $1>$ 에 제시한 바와 같다. 몸통 폄 근력은 $110^{\circ}$ 에서 pre에 $58.00 \mathrm{~kg}$ 과 비교해서 post에 $74.00 \mathrm{~kg}$ 으로 증가하였으며, $122^{\circ}$ 에서 pre에 $49.00 \mathrm{~kg}$ 과 비교해서 post에 $59.00 \mathrm{~kg}$ 으로 증가하였으며, $134^{\circ}$ 에서 $\mathrm{pre}$ 에 $46.00 \mathrm{~kg}$ 과 비교해서 post에 $55.00 \mathrm{~kg}$ 으로 증가하였으며, $146^{\circ}$ 에서 pre에 $41.00 \mathrm{~kg}$ 과 비교해서 post에 $47.00 \mathrm{~kg}$ 으로 증가하였으 며, $158^{\circ}$ 에서 pre에 $27.00 \mathrm{~kg}$ 과 비교해서 post에 34.00 $\mathrm{kg}$ 으로 증가하였으며, $170^{\circ}$ 에서 $\mathrm{pre}$ 에 $23.00 \mathrm{~kg}$ 과 비 교해서 post에 $27.00 \mathrm{~kg}$ 으로 증가하였다. 몸통 굽힘 근력은 $110^{\circ}$ 에서 pre에 $20.00 \mathrm{~kg}$ 과 비교해서 post에 $31.00 \mathrm{~kg}$ 으로 증가하였으며, $122^{\circ}$ 에서 pre에 $22.00 \mathrm{~kg}$ 과 비교해서 post에 $29.00 \mathrm{~kg}$ 으로 증가하였으며, $134^{\circ}$ 에서 pre에 $21.00 \mathrm{~kg}$ 과 비교해서 post에 $25.00 \mathrm{~kg}$ 으로 증가하였으며, $146^{\circ}$ 에서 $\mathrm{pre}$ 에 $18.00 \mathrm{~kg}$ 과 비교해서 post에 $26.00 \mathrm{~kg}$ 으로 증가하였으며, $158^{\circ}$ 에서 pre에 $16.00 \mathrm{~kg}$ 과 비교해서 post에 $25.00 \mathrm{~kg}$ 으로 증가하였으 며, $170^{\circ}$ 에서 pre에 $15.00 \mathrm{~kg}$ 과 비교해서 post에 23.00 $\mathrm{kg}$ 으로 증가하였다. $182^{\circ}$ 에서 pre에 $13.00 \mathrm{~kg}$ 과 비교해 서 post에 $22.00 \mathrm{~kg}$ 으로 증가하였다.
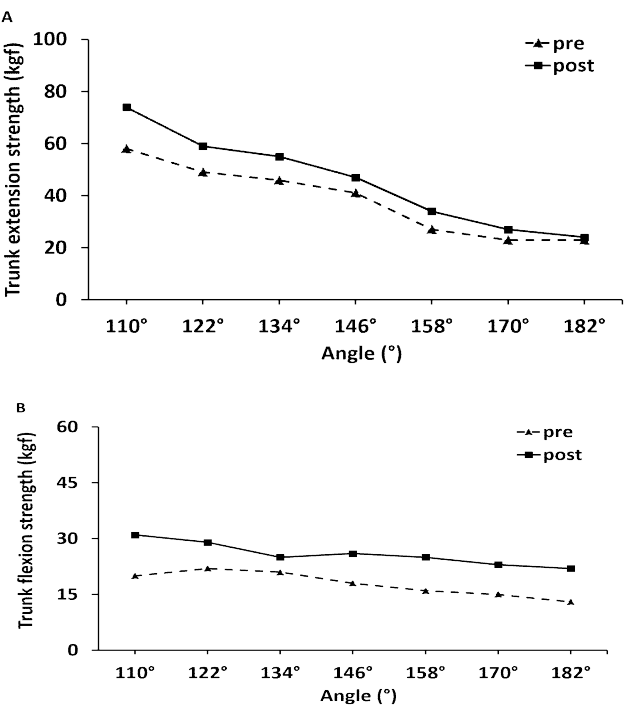

Fig. 1. Changes in trunk extensor $(A)$ and flexor $(B)$ strength before (pre) and after 4-week (post) corrective exercise

4) 허리척추앞굽음각 및 엉치 수평각의 변화

허리척추앞굽음각 및 엉치 수평각의 변화는 <Fig. $2>$ 에 제시한 바와 같다. 허리척추앞굽음각은 pre의 $62.19^{\circ}$ 와 비교해서 post에 $54.82^{\circ}$ 로 감소하였다. 엉치 수평각은 pre의 $45.17^{\circ}$ 와 비교해서 post에 $33.41^{\circ}$ 로 감 소하였다.

\section{논의}

이 사례연구에서는 $\mathrm{APT}$ 환자를 대상으로 단기간의 교정운동이 통증, 엉덩관절 가동범위 및 몸통 근력에 미치는 영향을 검토한 결과, 4 주간의 교정운동은 $\mathrm{APT}$ 환자의 통증 및 장애지수의 감소, 엉덩관절 가동범위 의 증가 및 몸통 폄 및 굽힘 근력 향상에 긍정적인 효과가 있다는 것을 확인하였다. 이상의 결과를 통해 이 사례연구에서의 교정운동은 $\mathrm{APT}$ 환자의 임상적인 효과가 있는 것으로 생각된다.

Kendall \& McCreary (1983)에 따르면 일반적으로 $\mathrm{APT}$ 는 요부 근육군 및 둔부근육의 경직과 복부근육 및 넙다리뒤근육의 약화와 같은 근육의 불균형에 의해 발생하며, $\mathrm{APT}$ 의 치료를 위해서는 근육의 불균형을 

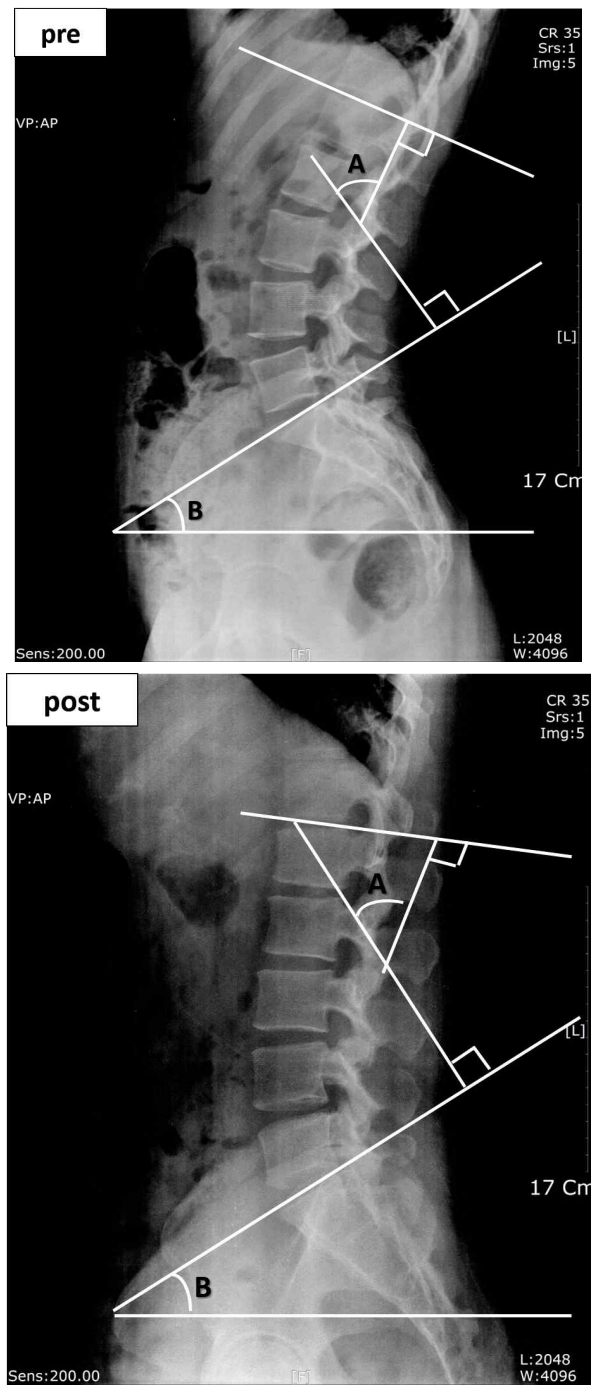

Fig. 2. Cobb's angle (A, pre: $62.19^{\circ}$, post: $54.82^{\circ}$ ) and sacral horizontal angle (B, pre: $45.17^{\circ}$, post: $\left.33.41^{\circ}\right)$ of the patient at the pre and post assessment

개선시키기 위한 자세 교정이 필요하다고 하였다. 또 한 Sahrmann (2002)은 APT의 치료를 위해서는 요부, 둔부 및 복부 근육군의 불균형 교정을 동시에 진행하 여야 하며, 단일 근육군의 강화를 목표로 한 교정운동 은 과도한 허리척추앞굽음, 허리골반 장애 및 $\mathrm{APT}$ 를 악화시킨다고 보고하였다. Chaitow (1996)은 APT환자 는 큰볼기근과 무릎관절 굴곡근 활성의 지연으로 인해 단일 근육군 교정운동 시 비정상적 움직임의 발생으로 인해 APT 및 허리척추앞굽음의 악화를 야기한다고 보 고하였다. 이 사례연구에서는 복부 근육군, 엉덩 근육
군, 넙다리 뒷근육 및 엉덩관절 벌림근의 강화와 척추 주변근, 엉덩관절 모음근 및 굽힘근의 신장을 통한 $\mathrm{APT}$ 및 허리척추앞굽음과 관련된 근육군들의 균형적 발달을 위한 교정운동 프로그램을 진행하였다.

$\mathrm{APT}$ 는 허리척추앞굽음을 야기하여 통증을 유발하는 주요원인 중 하나로(Suputtitada et al., 2002), 허리척추 앞굽음의 발생에 의한 척추 주변근육활성의 변화와 척 추인대 및 추간판(intervetebral disk)의 비정상적 부하 가 크게 증가되며, 그 결과로 중력에 따른 자세유지를 위한 등뼈의 뒤굽음 및 목뼈의 자세 변화를 발생시키 며(Levine et al., 1997), 장시간의 APT는 요부 및 골반 주변 근육, 인대, 관절의 비정상적 부하로 인해 다른 관절들의 자세를 변화시켜 통증 및 일상생활의 장애를 발생시킨다고 보고하였다(Toppenberg \& Bullock, 1986). Ross et al.(2014)은 골반경사의 변화는 골반 및 요부의 만성통증을 야기한다고 하였으며, Roussouly et $\mathrm{al}(2005)$ 은 APT로 발생한 골반과 요부 통증 및 요부의 퇴행성 변화를 감소시키기 위해서는 시상면(saggital plain)에서의 정렬이 필수적이라고 하였다. 이 사례연 구에서 VAS 및 ODI는 교정운동 전과 비교하여 운동 4 주 후에 각각 감소하는 것으로 나타났다. 따라서 이 사례연구에서 ATP 환자에게 적용한 교정운동은 요부 및 골반주변 근육, 인대, 관절의 비정상적 부하의 감소 와 더불어 시상면 정렬에 개선을 통해 통증 및 장애지 수가 감소되었을 가능성이 시사되었다.

엉덩관절은 보행 시 골반과 하지 사이의 움직임을 제공하며, 움직임이 일어나는 동안 관절의 안정성을 확보하는 역할을 한다(Kim et al., 2014). 또한 엉덩관 절 주변 근육은 전반적인 신체의 움직임에 관여하며, 보행 시 신체의 이동을 위한 회전력(torque)을 발생시 킨다고 하였다(Neumann, 2010). Jull \& Janda(1987)에 따르면 APT는 허리뼈의 비정상적 부하를 증가시킬 뿐만 아니라 엉덩관절 움직임에 장애를 발생시킨다고 하였으며, Pinto et al(2008)은 엉덩관절 가동범위의 감소는 움직임의 제한 및 관절의 뺏뺏함(stiffness)을 증가시켜 보행 및 일상생활능력의 감소를 발생시킨다 고 하였다. 또한 Hertel et al(2004)은 APT환자의 엉덩 관절 움직임 장애는 전방십자인대 손상의 위험성을 증가시킨다고 하였다. 이 사례연구에서 엉덩관절 가동 범위는 교정운동 전과 비교해서 운동 후의 굽힘, 폄, 
모음, 벌림, 안쪽 돌림 및 가쪽 돌림 모두에서 증가한 것으로 나타났다. 이러한 결과는 복부 근육군, 엉덩 근육군, 넙다리 뒷근육 및 엉덩관절 벌림근의 강화와 척추 주변근, 엉덩관절 모음근 및 굽힘근의 신장에 초 점을 맞춘 교정운동이 $\mathrm{APT}$ 를 감소시켜 엉덩관절 움 직임 장애를 감소시켰다고 생각된다.

전술한 바와 같이, $\mathrm{APT}$ 는 복부근육과 엉덩근육의 약화 및 몸통 폄근 및 넙다리뒷근육의 경직을 동반하 여 발생하며, $\mathrm{APT}$ 환자에게서 요골반의 안정과 신체 의 균형적 움직임을 위해서는 엉덩관절과 몸통의 균 형적 근육활성이 중요하다고 하였다(Tateuchi et al., 2013). 또 다른 선행연구에서는 APT는 코어 근육군의 근력 감소와 관련성이 있으며, 코어 근육군의 강화를 위한 운동처방이 필요하다고 하였다(Willson et al., 2005). 이 사례연구에서 몸통 폄 및 굽힘 근력은 교정 운동 전과 비교하여 교정운동 4 주 후에 증가하였으며, 특히 몸통 굽힘 근력의 전체적인 증가가 나타났다. Youdas et al(2000)에 따르면 APT는 복부 근력 약화 가 가장 주된 원인으로 복부근력의 강화는 골반의 후 방경사와 과도한 허리척추앞굽음을 감소시킬 수 있다 고 하였으며, Oh et al(2007)은 APT 환자에게서 단기 간의 복부근력 강화운동 시 $\mathrm{APT}$ 각도의 감소를 보였 다고 보고하였다. 이 사례연구에서는 몸통의 근력강화 를 포함한 교정운동이 몸통 굽힘 근력뿐만 아니라 몸 통 폄근의 강화를 통해 $\mathrm{APT}$ 를 개선시켰으며, 이를 통 해 엉덩관절 $\mathrm{ROM}$, 요부통증 및 장애의 감소에 긍정 적인 영향을 주었을 것으로 생각된다.

\section{결론}

이 사례연구에서는 단기간의 교정운동이 $\mathrm{APT}$ 환자 의 요통 및 요부장애지수의 감소, 엉덩관절 가동범위 와 몸통 굽힘 및 폄 근력의 향상에 긍정적인 효과가 있다는 것을 검증하였다. 향후에는 ATP 환자를 대상 으로 교정 운동의 일반화를 위해서는 보다 많은 피험 자를 대상으로 통증, 자세 및 근육활성 등에 미치는 상세한 효과를 검토할 필요가 있다고 생각된다.

\section{참고문헌}

Brodie, D. J., Burnett, J. V., Walker, J. M., \& Lydes-Reid, D. (1990). Evaluation of low back pain by patient questionnaires and therapist assessment. Journal of Orthopaedic \& Sports Physical Therapy, 11(11): 519-529.

Chaitow, L. (1996). Muscle energy techniques. Churchill Livingstone, London, England.

Choi, S. A., Cynn, H. S., Yi, C. H., Kwon, O. Y., Yoon, T. L., Choi, W. J., \& Lee, J. H. (2015). Isometric hip abduction using a Thera-Band alters gluteus maximus muscle activity and the anterior pelvic tilt angle during bridging exercise. Jaurnal of Electromyography and Kinesidogy, 25(2): 31031-5.

Endo, K., Suzuki, H., Nishimura, H., Tanaka, H., Shishido, T., \& Yamamoto, K. (2012). Sagittal lumbar and pelvic alignment in the standing and sitting positions. Jaumal of Orthopaedic Science, 17(6): 682-686.

Graves, J. E., Webb, D. C., Pollock, M. L., Matkozich, J., Leggett, S. H., Carpenter, D. M, Foster, D. N., \& Cirulli, J. (1994). Pelvic stabilization during resistance training. Its effect on the development of lumbar extension strength. Archives of Physical Medicine and Rehabilitation, 75: 210-215

Hertel, J., Dorfman, J. H. \& Braham, R. A. (2004). Lower extremity malalignments and anterior cruciate ligament injury history. Journal of Sports Science and Medicine, 3(4): 220-225.

Juhl, J. H, Ippolito Cremin, T. M., \& Russell, G. (2004). Prevalence of frontal plane pelvic postural asymmetry--part 1 . The Journal of the American Osteopathic Association, 104(10): 411-421.

Jull, G., \& Janda, V. (1987). Musdes and motor control in low back pain LT. Twomey, Physical Therapy 
for the Low Back Cinics in Physical Therapy, Churchill-Livingston, New York, USA

Kendall, F., \& McCreary, E. K. (1983). Muscles testing and function Lippincott Williams \& Wilkins, Baltimore, USA.

Kendall, P., Whynot, E., \& Gomber, E. (1977). A retrospective study of 191 cases of pelvic inflammatory disease. Canadian Jaurnal of Public Health, 68(4): 318-322

Kim, H. J., Chung, S., Kim, S., Shin, H., Lee, J., Kim, S., \& Song M. Y. (2006). Influences of trunk muscles on lumbar lordosis and sacral angle. European Spine Jaurnal, 15: 409-414.

Kim, Y., Kim, S., \& Jang, H. (2014). Correlation of Hip Joint Range of Motion and Femur Head Anterior Glide Mobility with Gait Ability in Stroke Patients. Journal of Korean Society of Physical Medicine, 9(1): 35-44.

Kisner, C. \& Colby, L. A. (2002). Therapeutic Exercise Foundations and Techniques. 4th Edn, Davis FA Company, Philadelphia, USA.

Lee, H. S. (2015). Enhanced muscle activity during lumbar extension exercise with pelvic stabilization. Journal of Exercise Rehabilitation, 11(6): 372-377.

Lee, H. S., \& Kim, A. R. (2016). The Effect of Corrective Exercise in a patient with knee joint valgus deformity: A single-subject A-B-A experimental design. Journal of Korean Society of Physical Medicine, 11(1): 93-105.

Levine, D., Walker, J. R., \& Tillman, L. J. (1997). The effect of abdominal muscle strengthening on pelvic tilt and lumbar lordosis. Physiotherapy Theory and Practice, 13(3): 217-226.

Little, D. G., \& MacDonald, D. (1994). The use of the percentage change in Oswestry Disability Index score as an outcome measure in lumbar spinal surgery. Spine (Phila Pa 1976), 19(19): 2139-2143.

López-Miñarro, P. A., Muyor, J. M., Belmonte, F., \&
Alacid, F. (2012). Acute effects of hamstring stretching on sagittal spinal curvatures and pelvic tilt. Jaurnal of Human Kinetics, 31: 69-78.

Mousavi, S. J., Parnianpour, M, Mehdian, H, Montazeri, A. \& Mobini, B. (2006). The Oswestry Disability Index, the Roland-Morris Disability Questionnaire, and the Quebec Back Pain Disability Scale: translation and validation studies of the Iranian versions. Spine (Phila Pa 1976), 31(14): E454459.

Neumann, D. A. (2010). Kinesiology of the hip: a focus on muscular actions. Jaurnal of Orthopaedic \& Sports Physical Therapy, 40(2): 82-94.

Oh, J. S., Cynn, H. S., Won, J. H., Kwon, O. Y., \& Yi, C. H. (2007). Effects of performing an abdominal drawing-in maneuver during prone hip extension exercises on hip and back extensor muscle activity and amount of anterior pelvic tilt. Jaurnal of Orthopaedic \& Sports Physical Therapy, 37(6): 320-324.

Pinto, R. Z., Souza, T. R., Trede, R G., Kirkwood, R. N., Figueiredo, E. M, \& Fonseca, S. T. (2008). Bilateral and unilateral increases in calcaneal eversion affect pelvic alignment in standing position. Manual Therapy, 13(6): 513-519.

Ross, J. R, Nepple, J. J., Philippon, M J., Kelly, B. T., Larson, C. M, \& Bedi, A (2014). Effect of changes in pelvic tilt on range of motion to impingement and radiographic parameters of acetabular morphologic characteristics. The American Jaurnal of Sparts Medaine, 42(10): 2402-2409.

Roussouly, P., Gollogly, S., Berthonnaud, E., \& Dimnet, J. (2005). Classification of the normal variation in the sagittal alignment of the human lumbar spine and pelvis in the standing position. Spine (Phila Pa 1976), 30(3): 346-353.

Sahrmann, S. A (2002). Does postural assessment 
contribute to patient care? Jaurnal of Orthopaedic \& Sports Physical Therapy, 32(8): 376-379.

Sarikaya, S., Ozdolap, S., Gümüstass, S., \& Koç, U. (2007). Low back pain and lumbar angles in Turkish coal miners. American Jaurnal of Industrial Medicine, 50: 92-96.

Schache, A. G., Blanch, P. D., \& Murphy, A. T. (2000). Relation of anterior pelvic tilt during running to clinical and kinematic measures of hip extension. British Journal of Sports Medicine, 34: 279-283.

Suputtitada, A., Wacharapreechanont, T., \& Chaisayan, P. (2002). Effect of the "sitting pelvic tilt exercise" during the third trimester in primigravidas on back pain. Journal of the Medical Association of Thailand, 85 Suppl 1: S170-179.

Tateuchi, H, Tsukagoshi, R., Fukumoto, Y., Akiyama, H, So, K., Kuroda, Y., \& Ichihashi, N. (2013). Pelvic instability and trunk and hip muscle recruitment patterns in patients with total hip arthroplasty. Journal of Electromyography and Kinesidogy, 23(1): 151-158.

Toppenberg, R. M., \& Bullock, M. I. (1986). The interrelation of spinal curves, pelvic tilt and muscle lengths in the adolescent female. Australian Journal of Physiotherapy, 32(1): 6-12.

Waryasz, G. R. (2010). Exercise Strategies to Prevent the Development of the Anterior Pelvic Tilt: Implications for Possible Prevention of Sports Hernias and Osteitis Pubis. The Journal of Strength \& Conditioning Research, 32(4): 56-65.

Willson, J. D., Dougherty, C. P., Ireland, M. L., \& Davis, I. M. (2005). Core stability and its relationship to lower extremity function and injury. Journal of the American Academy of Orthopaedic Surgeons, 13(5): 316-325.

Youdas, J. W., Garrett, T. R., Harmsen, S., Suman, V. J., \& Carey, J. R. (1996). Lumbar lordosis and pelvic inclination of asymptomatic adults. Physical Therapy Journal, 76(10): 1066-1081.

Youdas, J. W., Garrett, T. R., Egan, K. S., \& Therneau, T. M. (2000). Lumbar lordosis and pelvic inclination in adults with chronic low back pain. Physical Therapy Journal, 80(3): 261-275. 
